of the Congo Basin; French colonial expansion; modern political developments in Nigeria, Guinea, Mali, Tanganyika, Madagascar, and Uganda; economic and social problems of independent African countries; agrarian questions and workers' movements in tropical Africa; religious cults in tropical Africa; ethnographies of Nigeria and of Ethiopia; the Guinea slave trade and ancient Axum.

A two-volume encyclopedia, Afrika, has been published and a two-volume series ' Essays in recent and contemporary African history' is in preparation. An account of the work of the Moscow Institute has recently been contributed to the International Social Science Journal, vol. xvi, 1964, Pp. $431-3$.

University teaching of subjects in the field of African studies is organized independently of the institutes but some of the courses are given by members of their staffs.

\title{
Notices in Soviet Journals on the Occasion of the Sixtieth Birthdays of Professors Ol'derogge and Potekhin
}

Narody Azii i Afriki and Sovietskaya etnografiya have published notices of the careers of Professors Ol'derogge and Potekhin, from which the following accounts have been translated with acknowledgements.

D. A. Ol'derogge, Professor and Head of the Faculty of African Studies at the University of Leningrad, and Corresponding Member of the USSR Academy of Sciences, was born in 1903, fought as a youth in the Red Army in 1920-2, and studied in the ethno-linguistic faculty of Petrograd University under Professors U. V. Struve, V. Barthold, and N. D. Flitner.

On graduating he was appointed assistant in the Africa section of the Museum of Ethnography and Lecturer in the University in 1929. He defended his doctorate thesis (on the Gens Triplex system) in 1935. From 1934, in addition to his ethnographic lectures, he began teaching Hausa and Swahili at the Institute of Oriental Studies in Leningrad. A separate Faculty of African linguistic and ethnographic studies was created in the University in 1945, which Profesor $\mathrm{Ol}^{\prime}$ derogge has directed since its inception. His publications, from 1928 to date, cover lineage structure and kinship studies, language studies, notably Hausa, Arabic, Amharic, and Bantu languages, and studies in the pre-colonial history of the Sudan belt. Among his major works are: Benin Antiquities (1953, 1955, 1957); The Western Sudan in Isth to 19th centuries (1960); and the editorship and introductory sections of Narody Afriki (1954) and of Arabic Sources from 7 th to roth centuries on Africa South of the Sahara (1960). He is at present directing work on a series of dictionaries of African languages from and into Russian. His field studies include work in Egypt, Senegal, and Mali. Professor Ol'derogge is a member of several international learned bodies, including the Royal Anthropological Institute.

I. I. Potekhin, Professor and Director of the Africa Institute, Academy of Sciences, Moscow, was born in 1903, fought in the Red Army in Siberia, joined the Komsomol in 1920 and the C.P. in 1922. He studied at the Krasnoyarsk Party School and worked in party education until 1929, when he was again called up for army service (on the Chinese railway) until 1930 . On demobilization he combined study in the reconstituted Africa section of the Oriental Institute in Leningrad with organization work. In 1939 he was recalled to the army during the war with Finland, and in this period completed his doctoral thesis on Agriculcultural Organization among the Eastern Bantu. During the war Dr. Potekhin taught MarxismLeninism in the Higher Educational School for Officers. On demobilization in 1946 he turned wholly to academic work at the Institute of Ethnography of the Academy of Sciences in Moscow where he was deputy-director 1949-59. In that year the Africa Institute of the Academy of Sciences was constituted, and Professor Potekhin became its first Director, a post which he held until his death in 1964 . His publications began in 1932 with articles 
on labour questions in Africa, in The Negro Worker (Hamburg), Umzebenzi (under the pseudonym of John Izotla), and in Russian journals, and went on to studies of land tenure, social organization, and national movements in Southern, Central, and West Africa. His most important works are: The Growth and Formation of a National Community of the Southern African Bantu (1955), Ghana To-day (1958), Africa Looks to the Future (1960), African Socialism - an Answer to my Critics (1963). He edited for publication in Russian the classical works of Livingstone and Stanley, and more recently Peter Abrahams's Path of Thunder. He reviewed many books, including Mr. Kenyatta's Facing Mount Kenya (in Sov. etnografiya in 1948). He was co-editor with Professor Ol'derogge of Narody Afriki (1954), in which he wrote several sections, mainly on West Africa. He was editor in chief of an Africa encyclopaedia, the first volume of which was published in Moscow in 1963 . He wrote in Pravda and Izvestia as well as in professional journals, and as President of the Soviet-Africa Society carried out public engagements throughout the Soviet Union and abroad. His work overseas included a term spent in Legon University, Ghana, participation in congresses of learned societies, and work on the steering committee of the first congress of Africanists held in 1963 .

\section{'Africana'-Bulletin of the Centre of African Studies at the University of Warsan} THE first number of Africana, published by the Centre of African Studies at the University of Warsaw and edited by Professor Stefan Strelcyn, has just appeared. It contains scientific articles concerned with various aspects of African studies in Poland, reviews, and bibliographical notes of books and articles in Polish dealing with Africa. The languages of the bulletin are English and French; it will appear bi-annually and may be exchanged for journals or books of similar interests. Inquiries should be addressed to: Studium Afrykanistyczne, Uniwersytet Warszawski, Warszawa 64, Poland.

Articles in the first number include:

Les aspects sociaux de la première phase de l'expansion coloniale, by Marian Malowist.

Economic Planning in Africa, by Jan Halpern.

Un traité éthiopien d'hygiène et de diététiquè, by Stefan Strelcyn.

Birth Rates in Sudan, by Egon Vielrose.

Atlases and Serial Maps in Africa, by Bogodar Winid.

The second number will include:

La jeune élite africaine, by Andrzej Zajączkowski.

Employment and Economic Development in a Dual Economy, by Ignacy Sachs.

Économie paysanne dans les territoires coloniaux, by Andrzej Waligórski.

Patterns of New-coined Abstract Terms in Modern Swahili, by Rajmund Ohly.

L'Afrique noire dans le 'Kitāb al-Masālik wa-mamālik' d'Abu 'Ubayd al-Bekri, by Tadeusz Lewicki.

(Communicated by Professor St. Strelcyn)

\section{'The Sound of Africa' Series of Long Playing Records}

THE new catalogue of ' The Sound of Africa' series of long playing records lists some 3,000 items from Central and Southern Africa which are now available in I 28 African languages on 210 records. They have been collected and classified with a card index for African composers and musicians, universities, colleges of music, and all students of the indigenous arts of Central and Southern Africa. Orders and inquiries should be addressed to: The Director, International Library of African Music, P.O. Box 138, Roodepoort, Nr. Johannesburg, South Africa.

In his introduction to the catalogue the Director, Mr. Hugh Tracey, recalls his long 